\title{
Enteroviruses as a possible cause of hypertension, dilated cardiomyopathy (DCM) and hypertensive heart failure (HHF) in South western Nigeria
}

\author{
*Okonko $\mathrm{IO}^{1}$, Adebiyi AA², Ogah $\mathrm{OS}^{3}$, Adu FD $\mathrm{FD}^{4}$
}

1. Medical Microbiology\& Virology Unit, Department of Microbiology, University of Port Harcourt, EastWest Road, P.M.B. 5323, Choba, Port Harcourt, Rivers State, Nigeria;

2. Cardiology Unit, Department of Medicine, College of Medicine, University of Ibadan, Ibadan, Nigeria

3. Division of Cardiology, Department of Medicine, University College Hospital, Ibadan, Nigeria

4. Department of Virology, College of Medicine, University of Ibadan, Ibadan, Nigeria

\begin{abstract}
Background: Human enteroviruses have long been associated with various diseases of man resulting into a wide range of acute symptoms involving the cardiac and skeletal muscles, central nervous system, pancreas, skin and mucous membranes. Objective: To assess the role of enteroviruses in the etiology of hypertension, DCM and HHF.

Methods: We obtained stool specimens from 70 subjects comprising 65 patients and 5 controls and isolation was carried out on RD, L20B, HEp-2C and Vero cell lines and identified by neutralization with standard antisera (RIVM). Thirty-six enteroviruses were isolated and identified to be Coxsackieviruses-B5, A9, Echoviruses 1, 6, 7, 9, 11, 12, 22, 30 and Poliovirus type 1 and 3 .

Results: Three most frequently occurring enterovirus serotypes which constitute $60.0 \%$ of the 30 NPEV typed and $50.0 \%$ of all the isolates were Echoviruses, Coxsackie-B5-virus and Coxsackievirus-A9. Echoviruses constituted $50.0 \%$ of all the serotypes while Coxsackieviruses-B5 and A9 accounts for the $27.8 \%$ and 5.6\% respectively. Enteroviral isolation rate was higher in age groups 51 years and above. The percentage of study subjects who had Coxsackie-B5-viruses and echoviruses was significantly $(\mathrm{P}<0.05)$ higher in cases of hypertension, HHF and DCM than in control subjects. Coxackie-B5-virus, Echovirus-6 and Echovirus-11 were found in both study locations.

Conclusion: The findings of this study showed that Enteroviruses may likely be involved in the etiology of hypertension, DCM and HHF. Further studies would therefore be necessary for the prevention and control of these diseases.

Keywords: Etiology, coxsackieviruses, Echoviruses, dilated cardiomyopathy (DCM), Enteroviruses, hypertension, hypertensive heart failure (HHF).

African Health Sciences 2013; 13(4): 1098 - 1106 http:/ /dx.doi.org/10.4314/ahs.v13i4.34
\end{abstract}

\section{Introduction}

Human enteroviruses have long been associated with various diseases of man resulting into a wide range of acute symptoms involving the cardiac and skeletal muscles, central nervous system, pancreas, skin and mucous membranes ${ }^{1-2}$. Their roles in chronic diseases such as the dilated cardiomyopathy, insulin -

*Corresponding author:
Iheanyi O. Okonko
Medical Microbiology \& Virology unit
Department of Microbiology
University of Port Harcourt
P.M.B. 5323
Choba, East-West Road, Port Harcourt, Rivers
State
Nigeria
Tel: +2348035380891
E-mail: iheanyi.okonko@uniport.edu.ng,
mac2finney@yahoo.com

dependent diabetes mellitus, motor neurone disease, chronic fatique syndrome and postpoliomyelitis, syndrome have also been documented ${ }^{3-8}$. Worldwide, an estimated one billion infections occur each year?.

Enteroviruses (EVs), particularly the Coxsackie $\mathrm{B}$ viruses, are cardiotropic and are important causes of myopericarditis in children and adults ${ }^{10,11}$ and are associated with the pathogenesis of dilated cardiomyopathy ${ }^{12-13}$. Recent polymerase chain reaction (PCR) studies in human myocardium have provided evidence that enteroviral infection was detectable in acute and chronic myocarditis, as well as, in end-stage idiopathic dilated cardiomyopathy (IDCM $)^{10,13}$. Some, but not all, studies suggested that positive PCR for virus may be an unfavourable predictor, and it has been proposed that additional prospective data are needed ${ }^{14}$. In a prospective study, Heymans ${ }^{15}$ assessed aetiopathogenesisin myocarditis, 
including a positive PCR for virus and serum as viral and autoimmune markers.

Previousstudies by Mahrholdt et al. ${ }^{16}$; Heymans et al. ${ }^{17}$; Heymans ${ }^{15}$; Maekawa et al. ${ }^{18}$ and Caforio et al. ${ }^{19}$ have also shown that many viruses are capable of damaging the heart during their replication which often causes damage to the heart cells in $25-50 \%$ of all cases of acute heart failure. Pauschinger et al. ${ }^{20}$ found 24 of 94 patients with IDCM leading to heart failure to have either adenoviral or enteroviral polymerase chain reaction positivity from clinical heart samples.

Cardiomyopathy been reported to be associated with viruses like coxsackieviruses, adenovirus, and echovirus. Enteroviruses and adenoviruses have been considered the most common pathogens of viral cardiomyopathy, but parvovirus B19 (PVB19) is increasingly found in endomyocardial biopsies of patients with acute myocarditis or IDCM $^{16,21}$. Recent biopsy series in patients with DCM have revealed that long-term persistence of cardiotropic viruses triggers heart failure at long term: $>70 \%$ of patients with DCM carry a cardiotropic virus in the heart as reported by Tschope et al. ${ }^{22}$ and Kuhl et $a .^{23}$.

Isolation and identification of enteroviruses is important to establish an etiologic/epidemiologic link among cases during an outbreak and to recognize serotype-specific cases, such as dilated cardiomyopathy and hypertensive heart failures. Confirmation of a suspected enterovirus infection is important for management of patient, prognosis, reducing hospitalization, preventing outbreaks, and excluding other infectious diseases, and therefore prevents unprescribed antibiotic usage. In addition, rapid confirmatory diagnosis of enteroviral infections could facilitate use of the novel antiviral drugs, such as pleconaril, targeted at the Picornaviridae ${ }^{24-26}$. However, the impact of the endemic enteroviral infection on the cardiovascular system in Africans has received scanty attention by researchers. There is, however, dearth of literatures on the precise role or contributions of enteroviruses in the pathogenesis of DCM and HHF in Nigeria. Thus, this study attempted to isolate and identify enteroviruses as a possible cause of hypertension, DCM and HHF in South Western Nigeria.

\section{Methods}

\section{Study Area}

All of the patients used for this study came from Ibadan city in Oyo state, one of the largest city in Africa and

African Health Sciences Vol 13 Issue 4 December 2013 its immediate environs and few were from Abeokuta and its envirions both in South- Western, Nigeria.

\section{Study Population}

Informed consent was obtained from each patient before investigations were carried out. A total of seventy (70) subjects (comprising 65 patients and 5 controls) were selected for studies based on M-mode echocardiography (ages 4-83 years; mean age: 49.7 years). The 65 study subjects comprised 48 (73.8\%) males and $17(26.2 \%)$ females (Table 3) while the control groups comprised $4(80.0 \%)$ males and $1(20.0 \%)$ female (Table 4$)$. The study subjects were so confirmed of the clinical condition by the Consultant Cardiologists. The control subjects were also so confirmed free of the clinical conditions. Demographic and clinical information of the subjects were obtained by chart abstraction and recorded on a prepared data collection form. Other relevant information such as socio-economic status, occupation, history of smoking and alcohol intakes and parity (females only) were obtained using a Performa specially designed for this purpose.

\section{Sample collection}

Stool samples were collected aseptically from the subjects ( 65 patients and 5 controls) and the laboratory investigation such as viral isolation and identification carried out according to standard laboratory procedures of WHO manual ${ }^{28}$. All specimens were collected aseptically and transported in cold chain. The 70 samples from 65 patients and 5 controls were analyzed anonymously, as required by ethical rules ${ }^{27}$.

\section{Specimens preparation for virus isolation}

All stool samples were treated with chloroform before inoculation into cell culture ${ }^{28}$.

\section{Cell lines and tissue culture media}

Green monkey kidney (Vero), human epidermoid carcinoma (HEp-2) and human rhabdomyosarcoma (RD), and genitically engineered mouse cell (L20B) lines were used in this study ${ }^{28}$. With adherence to aseptic procedures and $\mathrm{WHO}^{28}$ protocols, cells seeded into test tubes and at specified cell concentrations. Cell lines were cultured in Eagle's minimum essential medium with Earle's salts (Gibco, Invitrogen, Paisley, UK/ Gibco, BRL, Grand Island, N.Y.) supplemented with $5 \% / 10 \%$ fetal bovine serum, $2 \mathrm{mM}$ Lglutamine, 26.8 $\mathrm{mM} \mathrm{NaHCO} 3,100 \mathrm{U}$ of penicillin per $\mathrm{ml}$, and $100 \mathrm{~g}$ of streptomycin per $\mathrm{ml}$ and amphotericin B [0.25g/ $\mathrm{ml}])$. All tissue culture media and reagents were composed and prepared according to the working 
standard method described by $\mathrm{WHO}^{28}$ for the virologic investigation of enteroviruses.

\section{Virus isolation}

Virus isolation and in vitro propagation was carried out using Vero, HEp-2, RD and L20B and all processed stool samples were inoculated onto monolayers of these four different cell lines and incubated in the stationary sloped position at $37^{\circ} \mathrm{C}$. The cultured tubes were observed daily, using a standard/inverted microscope, for appearance of cytopathic effect (CPE) characteristic for enterovirus for the first 7 days; day 10 and finally at 14 days post-inoculation as described by $\mathrm{WHO}^{28}$.

\section{Virus identification}

Poilo and NPEVs isolated in this study were identified using specific polyclonal antisera as described by the $\mathrm{WHO}^{28}$ standard protocols for identifications of polio and non-polio enteroviruses.

\section{Antisera}

Pooled horse antisera against the most frequently isolated ECHO and Coxsackieviruses were provided by the National Institute of Public Health and the Environment (RIVM), Bilthoven, The Netherlands. Interpretation of the results was done with the assistance of a list of the neutralization patterns of individual viruses ${ }^{28}$.

\section{Identification by Neutralization Assay}

Identification of virus serotypes was performed by neutralization test using type-specific antisera (National
Institute of Public Health and the Environment, The Netherlands) as described by $\mathrm{WHO}^{28}$.

\section{Virus titration}

Virus titre was determined by measuring TCID $_{50}$ of each virus isolate in $\mathrm{RD}$ cells, as previously described ${ }^{28}$.

\section{Results}

\section{Virus isolations}

A total of 36 isolates belonging to 10 clearly defined enterovirus serotypes were recovered from samples collected from the subjects confirmed to be DCM and HHF. One of the 36 isolates was recovered from the control group. The cell line of the positive samples showed cellular degeneration as cytopathic effect (CPE) which was very rapid, becoming $4^{+}$in 1-3 days with all cells detached from the glass base. CPE for the remaining enteroviruses generally requires 4-7 days or longer and often accompanied by individual small, round, and sometimes refractile cells or by a degenerative appearance across the monolayer, and might not progress to $4^{+}$or general cell lysis. CPE for the remaining were not specific for enteroviruses and were not tested further.

\section{Virus typing and identification}

Table 1 shows the frequency of enteroviruses among the various studied groups. The 10 serotypes were identified as Coxsackie-B5-viruses [10 (27.8\%)], echovirus 6 and 11 [4 (11.1\%) each], echovirus 7, 9, 12 , and $30[2(5.6 \%)$ each], Coxsackievirus A9 [2(5.6\%)], poliovirus (PV) type 1 [2(5.6\%)], PV3 [2(5.6\%)] and mixture of PV1 and PV3 [2(5.6\%)], and echovirus 1 and 22 [1 (2.8\%) each] as shown in table 1.

Table 1: Frequency of Occurrence of Enteroviral Isolates

\begin{tabular}{lcccccc}
\hline Enteroviral Isolates & No. (\%) & \multicolumn{2}{c}{ Subjects (\%) } & \multicolumn{2}{c}{ Locations (\%) } \\
\cline { 3 - 5 } & & $\begin{array}{c}\text { Study } \\
\text { Groups }\end{array}$ & $\begin{array}{c}\text { Control } \\
\text { Groups }\end{array}$ & FMC, & UCH, \\
\hline Coxsackie-B5-virus & $10(27.8)$ & + & - & + & + \\
Echovirus 7 & $2(5.6)$ & + & - & - & + \\
Echovirus 11 & $4(11.1)$ & + & - & + & + \\
Echovirus 9 & $2(5.6)$ & + & - & - & + \\
Echovirus 6 & $4(11.1)$ & + & - & + & + \\
Coxsackievirus-A9 & $2(5.6)$ & + & - & + & + \\
Echovirus 1 & 1 & $(2.8)$ & + & - & + & - \\
Echovirus 22 & $1(2.8)$ & + & - & + & - \\
Echovirus 12 & $2(5.6)$ & + & - & + & + \\
Echovirus 30 & $2(5.6)$ & + & - & - & + \\
Poliovirus 1 (PV1) & $2(5.6)$ & + & - & + & + \\
Poliovirus 3 (PV3) & $2(5.6)$ & + & - & + & + \\
PV1+PV3 Mixtures & $2(5.6)$ & + & + & + & + \\
Total & $\mathbf{3 6}(\mathbf{1 0 0 . 0})$ & $\mathbf{3 5 ( 9 7 . 2 )}$ & $\mathbf{1 ( 2 . 8 )}$ & $\mathbf{7 ( 1 9 . 4 )}$ & $\mathbf{2 9 ( 8 0 . 6 )}$ \\
\hline
\end{tabular}


Distribution of Enterovirus Isolates in relation to the group studied

Table 2 shows the distribution of enterovirus isolates in relation to patient groups studied. It showed that enteroviral infection was most prevalent among study subjects with DCM [26(63.4\%)], followed by hypertensives $[8(40.0 \%)]$, and HHF $[1(25.0 \%)]$. However, one $(20.0 \%)$ of the controls was positive for enterovirus.
Distribution of Enterovirus Isolates in relation to Location of study

Table 3 shows distribution of enterovirus isolates in relation to locations of study. It showed that enteroviral infection was more prevalent among subjects at FMC, Abeokuta [6(60.0\%)] than their counterparts at $\mathrm{UCH}$, Ibadan [29(52.7\%)]. It also showed that $1(50.0 \%)$ of the two controls from Abeokuta was positive for enterovirus (table 3).

Table 2: Distribution of Enteroviruses in relation to the groups studied

\begin{tabular}{|c|c|c|c|c|c|}
\hline Study Groups & $\begin{array}{l}\text { No. } \\
\text { Tested } \\
(\%)\end{array}$ & $\begin{array}{l}\text { No. } \\
\text { Positive } \\
(\%)\end{array}$ & Control Groups & $\begin{array}{l}\text { No. } \\
\text { Tested } \\
(\%)\end{array}$ & $\begin{array}{l}\text { No. Positive } \\
(\%)\end{array}$ \\
\hline Normotensives & $0(0.0)$ & $0(0.0)$ & Normotensives & $5(100.0)$ & $1(20.0)$ \\
\hline Hypertensives & $20(30.8)$ & $8(40.0)$ & Hypertensives & $0(0.0)$ & $0(0.0)$ \\
\hline $\begin{array}{l}\text { Hypertensive Heart } \\
\text { failure }\end{array}$ & $4(6.2)$ & $1(25.0)$ & Hypertensive Heart failure & $0(0.0)$ & $0(0.0)$ \\
\hline $\begin{array}{l}\text { Dilated Cardiomyopathy } \\
\text { Total }\end{array}$ & $\begin{array}{l}41(63.1) \\
\mathbf{6 5 ( 1 0 0 . 0 )}\end{array}$ & $\begin{array}{l}26(63.4) \\
35(53.8)\end{array}$ & $\begin{array}{l}\text { Dilated Cardiomyopathy } \\
\text { Total }\end{array}$ & $\begin{array}{l}0(0.0) \\
\mathbf{5 ( 1 0 0 . 0 )}\end{array}$ & $\begin{array}{l}0(0.0) \\
1(20.0)\end{array}$ \\
\hline
\end{tabular}

Table 3: Distribution of Enterovirus isolates in relation to locations studied

\begin{tabular}{lcc}
\hline Gender & No. Tested (\%) & No. Positive (\%) \\
\hline Study groups & & \\
UCH, & $55(84.6)$ & $29(52.7)$ \\
FMC, & $10(15.4)$ & $6(60.0)$ \\
Total & $\mathbf{6 5 ( 1 0 0 . 0 )}$ & $\mathbf{3 5 ( 5 3 . 8 )}$ \\
Control groups & & \\
UCH, & $3(82.9)$ & $0(0.0)$ \\
FMC, & $2(17.1)$ & $1(50.0)$ \\
Total & $\mathbf{5 ( 1 0 0 . 0 )}$ & $\mathbf{1 ( 2 0 . 0 )}$ \\
\hline
\end{tabular}

Distribution of Enterovirus Isolates in relation to various risk factors and demographics of subjects

Table 4 shows the distribution of enterovirus isolates in relation to various risk factors and demographics of study subjects. It showed that enteroviral infection was more prevalent among ages 51 years and above [19(54.3\%)] compared to their counterparts in ages below 51 years [16(53.3\%)]. However, this difference was not statistically significant $(\mathrm{p}>0.05)$. The distribution of enteroviruses in relation to sex is shown in table 4. It showed that enteroviral infection was more prevalent among males [27(56.3\%)] compared to their female counterparts [8(47.1\%)]. The results showed that the enterovirus isolates occurred frequently among the low-income class subjects $(73.5 \%)$ and high-income class subjects (60.0\%) compared to their counterparts in the 4 member-middle class $(19.0 \%)$. There was a significant difference in the rate of enteroviral infection between subjects in the high and the low socio-economic groups $(\mathrm{p}<0.05)$.

Enteroviral isolates were more prevalent among farmers $(100.0 \%)$. This was followed by businessmen and unemployed subjects $(66.7 \%$ each), traders $(61.0 \%)$, civil servants $(60.0 \%)$, students (57.1\%), clergy, custom officer and pensioners $(50.0 \%$ each). Enteroviral isolates were least prevalent among professionals $(25.0 \%)$ while no enterovirus isolates was obtained from the teachers studied (table 4).

From table 4, it showed that enteroviral infection was highest among subjects with history of heart failure (63.4\%), hypertension (56.1\%), DCM (61.0\%), alcoholics $(73.3 \%)$, smoking $(75.0 \%)$, and multiparious females $(66.7 \%)$ compared to their 
counterparts without such history. Females with no history of pregnancy (nulliparious) had the least enteroviral infection rate $(12.5 \%)$. There was a significant association $(\mathrm{p}<0.05)$ between the rate of enterovirus infection and clinical history of subjects (table 4). Statistically, enterovirus isolation rate was significantly $(\mathrm{p}<0.05)$ higher in those with hypertension, DCM and HHF than those in the control group (table 4).
Table 4 shows the distribution of enterovirus isolates in relation to various risk factors and demographics of control subjects. It showed that enteroviral infection was only found among male control subject age 51 years and above [1(25.0\%)]. The control results also showed that the enterovirus isolates occurred only among the low-income class and a farmer (table 4). Statistically, enterovirus isolation rate was significantly $(p<0.05)$ higher in the study group than the control group (table 4).

Table 4: Distribution of Enterovirus Isolates in relation to Risk factors among the study groups

\begin{tabular}{|c|c|c|c|c|}
\hline \multirow[t]{2}{*}{ Risk Factors } & \multicolumn{2}{|c|}{ Study Groups } & \multicolumn{2}{|c|}{ Control Groups } \\
\hline & $\begin{array}{l}\text { No. Tested } \\
(\%)\end{array}$ & $\begin{array}{l}\text { No. Positive } \\
(\%)\end{array}$ & $\begin{array}{ll}\text { No. } & \text { Tested } \\
(\%) & \end{array}$ & No. Positive ( $\%)$ \\
\hline \multicolumn{5}{|l|}{ Age group (years) } \\
\hline Below 51 & $30(44.6)$ & $16(53.3)$ & $1(20.0)$ & $0(0.0)$ \\
\hline 51 and above & $35(55.4)$ & $19(54.3)$ & $4(80.0)$ & $1(25.0)$ \\
\hline \multicolumn{5}{|l|}{ Gender } \\
\hline Male & $48(73.8)$ & $27(56.3)$ & $4(80.0)$ & $1(25.0)$ \\
\hline Female & $17(26.2)$ & $8(47.2)$ & $1(20.0)$ & $0(0.0)$ \\
\hline \multicolumn{5}{|l|}{ Clinical History } \\
\hline \multicolumn{5}{|l|}{ History of Heart Failure } \\
\hline Yes & $41(63.1)$ & $26(63.4)$ & $0(0.0)$ & $0(0.0)$ \\
\hline No & $24(36.9)$ & $9(37.5)$ & $5(100.0)$ & $1(20.0)$ \\
\hline \multicolumn{5}{|l|}{ History of Hypertension } \\
\hline Yes & $41(63.1)$ & $23(56.1)$ & $0(0.0)$ & $0(0.0)$ \\
\hline No & $24(36.9)$ & $12(50.0)$ & $5(100.0)$ & $1(20.0)$ \\
\hline \multicolumn{5}{|l|}{ History of DCM } \\
\hline Yes & $41(63.1)$ & $25(61.0)$ & $0(0.0)$ & $0(0.0)$ \\
\hline No & $24(36.9)$ & $10(41.7)$ & $5(100.0)$ & $1(20.0)$ \\
\hline \multicolumn{5}{|l|}{ History of Alcohol } \\
\hline Yes & $15(23.1)$ & $11(73.3)$ & $0(0.0)$ & $0(0.0)$ \\
\hline No & $50(76.9)$ & $24(48.0)$ & $5(100.0)$ & $1(20.0)$ \\
\hline \multicolumn{5}{|l|}{ History of Smoking } \\
\hline Yes & $12(18.5)$ & $9(75.0)$ & $0(0.0)$ & $0(0.0)$ \\
\hline No & $53(81.5)$ & $26(49.0)$ & $5(100.0)$ & $1(20.0)$ \\
\hline \multicolumn{5}{|l|}{ Parity (Females; $n=17$ ) } \\
\hline Below 4 & $4(23.5)$ & $2(50.0)$ & $0(0.0)$ & $0(0.0)$ \\
\hline Multiparity (4 and above) & $6(35.3)$ & $4(66.7)$ & $0(0.0)$ & $0(0.0)$ \\
\hline Nulliparity & $7(41.2)$ & $1(14.3)$ & $1(100.0)$ & $0(0.0)$ \\
\hline \multicolumn{5}{|l|}{ Socio-economic Class } \\
\hline High Income Class & $10(15.4)$ & $6(60.0)$ & $0(0.0)$ & $0(0.0)$ \\
\hline Middle Income Class & $21(32.3)$ & $4(19.0)$ & $3(60.0)$ & $0(0.0)$ \\
\hline Low Income Class & $34(52.3)$ & $25(73.5)$ & $2(40.0)$ & $1(50.0)$ \\
\hline \multicolumn{5}{|l|}{ Occupations } \\
\hline Students & $7(10.8)$ & $4(57.1)$ & $2(40.0)$ & $0(0.0)$ \\
\hline Farmers & $2(3.1)$ & $2(100.0)$ & $0(0.0)$ & $0(0.0)$ \\
\hline Traders & $23(35.4)$ & $14(61.0)$ & $2(40.0)$ & $1(50.0)$ \\
\hline Civil servants & $10(15.4)$ & $6(60.0)$ & $1(20.0)$ & $0(0.0)$ \\
\hline Pensioner & $2(3.1)$ & $1(50.0)$ & $0(0.0)$ & $0(0.0)$ \\
\hline Businessmen & $3(4.6)$ & $2(66.7)$ & $0(0.0)$ & $0(0.0)$ \\
\hline Teachers & $3(4.6)$ & $0(0.0)$ & $0(0.0)$ & $0(0.0)$ \\
\hline Custom officer & $2(3.1)$ & $1(50.0)$ & $0(0.0)$ & $0(0.0)$ \\
\hline Professionals & $8(12.3)$ & $2(25.0)$ & $0(0.0)$ & $0(0.0)$ \\
\hline Clergy & $2(3.1)$ & $1(50.0)$ & $0(0.0)$ & $0(0.0)$ \\
\hline Unemployed & $3(4.6)$ & $2(66.7)$ & $0(0.0)$ & $0(0.0)$ \\
\hline Total & $65(100.0)$ & $35(53.8)$ & $5(100.0)$ & $1(20.0)$ \\
\hline
\end{tabular}




\section{Discussion}

This study examined stool samples of hospital inpatients and outpatients with hypertension, Hypertensive heart failure (HHF), and dilated cardiomyopathy (DCM). Subjects with normal blood pressure were used as control. The study showed that enterovirus isolation rate was significantly $(\mathrm{p}<0.05)$ higher in those with hypertension, DCM and HHF than those in the control group. Among the enteroviruses isolated, echoviruses and CoxsackieB5-viruses were the most implicated. Enteroviral infection is thought to be the most common cause of HHF and DCM leading to heart failure. Many studies have evaluated the role of enterovirus infections (particularly Coxsackieviruses B4 and B5) as environmental triggers of diseases. Several lines of evidence also suggested that enterovirus infections may be involved in the etiology of the dilated cardiomyopathy (DCM) leading to heart failure and hypertensive heart failures ${ }^{11-13,29-31}$.

The pattern of distribution of each of the 10 identified NPEV serotypes differs in each of the 2 location studied with Coxsackie-B5-virus, Coxsackievirus A9, Echoviruses 1, 6, 9, 11, 12, 22 and 30, as well as, Polioviruses present in the 2 locations studied. Echoviruses 7, 9 and 30 were isolated only from patients in Ibadan. The findings of this present study suggest that enteroviruses are endemic in Nigeria and the frequency of occurrence among this patients studied is higher compare to other studies ${ }^{32}{ }_{-}^{37}$. Previous study in Nigeria suggested that Coxsackievirus B infections have been associated with clinical manifestation of DCM and $\mathrm{HHF}^{4}$. Muir et al..$^{30}$ reported a significantly higher prevalence of enterovirus-specific IgM responses among patients with DCM.

The three most frequently occurring enterovirus serotypes which constitute $60.0 \%$ of the 30 NPEV typed and $50.0 \%$ of all the isolates were Echoviruses, Coxsackie-B-viruses and Coxsackievirus A9. Coxackie-B5-virus was found in the two study locations in Ibadan and Abeokuta. Echovirus-6 and 11 was also found in both locations. Statistically, enterovirus isolation rate was significantly $(\mathrm{P}<0.05)$ higher in the study group than the control group. Occurrence of echovirus-6 was also documented as localized in Spain ${ }^{38}$, while both echovirus- 6 and 11 had been implicated in an outbreak of mixed enterovirus infections in Kansas $\mathrm{City}^{39}$. In a study by Li et al. ${ }^{11}$, nine of 14 myocardial samples from endemic DCM cases in China were positive for the enteroviral RNA. The isolation of echovirus 9 and 12 in this study deviates from the findings of Adejokun ${ }^{36}$ who reported the absence of these two serotypes in their study.

The isolation of Enteroviruses in this study gives an indication that enteroviral infection may likely have a role in the etiology of the different diseases studied. Our finding is similar to the work of Antia ${ }^{40}$ who found Coxsackievirus in the stool of one out of five children with DCM who later developed heart failure. It is also similar to Adejokun ${ }^{36}$ who reported Coxsackie-B-virus, Coxackievirus A9, echovirus 6,7 and 11 in patients who presented with DCM in Ibadan.

The study showed significant association between the enteroviral infection and the socioeconomic status of the subjects. The presence of these enteroviruses in the subjects were not surprising, it may have been probably due to over-crowding, poor sewage disposal and poor living standard notably in the two locations of study. The findings of this study also showed significant association $(\mathrm{P}<0.05)$ between enteroviral infection and clinical history of subjects. In keeping with others ${ }^{19,32,41-43}$, this study found frequency of enteroviral infections to be higher among subjects with DCM (63.4\%) than hypertensives $(40.0 \%)$ and $\operatorname{HHF}(25.0 \%)$, supporting a causative association in adults. Frequencies of the individual viruses have been highly variable. The differences in the frequency of occurrences of these isolates were also reported by previous studies ${ }^{14,23,36,43-46}$.

Our findings are comparable to that of Ferreira et al. ${ }^{29}$ and Fujioka et $a .^{45}$ who isolated enteroviruses; Coxsackie-B-viruses and echovirus-1 from DCM patients. All these previous reports and our present findings support the enteroviral involvement (especially group B and group A Coxsackieviruses) in the aetiology of DCM and HHF $^{11-13,29-31}$. Wojnicz et al. ${ }^{47}$ reported that $18(40.0 \%)$ among patients with left ventricle (LV) dysfunction demonstrated nonreplicative enterovirus. Wojnicz et al. ${ }^{47}$ also reported that $10(56.0 \%)$ out of 18 patients with left ventricle (LV) dysfunction were found to have active viral replication. Why et al. ${ }^{32}$ reported $34.0 \%$ prevalence of enteroviral infection among patients with idiopathic dilated cardiomyopathy (IDCM). A recent cross-sectional study has reported a much higher frequency of positive PCR for one or more viruses in patients with idiopathic LV dysfunction ${ }^{21}$ or $\mathrm{LV}$ diastolic dysfunction in the absence of myocarditis ${ }^{22}$. 


\section{Conclusion}

The higher frequency of echoviruses and CoxsackieB5-viruses as well as the presence of other enteroviral serotypes in this study suggest the possible association of these viruses in the etiology of HHF and DCM patients as have been previously reported by earlier workers. Attention must be directed toward currently recognized cardiotropic viruses and remain alert to the possibility that other viruses are common cardiac pathogens. Thus, this study further confirms the continued circulation of NPEV among hypertensives, HHF and DCM patients in Nigeria.

\section{Acknowledgement}

Our deep and sincere gratitude goes to all those who voluntarily participated in this study. The authors would like to thank management and staff of World Health Organization Regional Reference Laboratory for Polio, Department of Virology, College of Medicine, University of Ibadan for their support throughout the period of this study. Our gratitude also goes to the management and staff of Cardiology Unit, Department of Medicine, College of Medicine, University of Ibadan for their support throughout the period of this study. The support of the management and staff of Cardiology Unit, Department of Medicine, Federal Medical Centre, Abeokuta were also acknowledged. The excellent technical assistance of Dr. OG Oyero, Dr. MO Adewumi, Dr. Ochulor, Dr. (Mrs.) Enakpene, Dr. Bola Oyemankinde, Mr. E. Donbraye, Mr. O. Abidemi, Mr. Adeyemi, Mrs. OA Akanbi, Mrs Olufunke Oyero, Miss Olusola Oyetunde, Miss Olufunke Adewale, Mr. Tope Ogundiran and Mr. Oluwaseun Adedeji is sincerely acknowledged.

\section{References}

1. Melnick JL. Enteroviruses: Polioviruses, coxsackieviruses, echoviruses and newer enteroviruses in: Fields virology. Fields BN, Knipe DM, Melnick JL, Chanock RM, Roizmann B, Shope RE (Ed.) New York: Raven press. 1985, 739-794

2. Modlin JF. Coxsackiviruses, echoviruses and newer enteroviruses in: Principles and practice of infectious diseases. Mandel GL, Bennett JE, Dolin R (Ed.). New York: Churchill Livingstone. 1995, 1620-1636

3. Falase AO, Fabiyi A, Odegbo-Olukoya OO. Coxsackie $\mathrm{B}$ viruses and heart muscle diseases in Nigerian adults. Trop. Geog. Med 1978; 31; 237243.

4. Falase AO, Sekoni GA, Adenle AD. Dilated cardiomyopathy in young adult Africans, sequel to infections? African Journal of Medical Science 1982; 11: 1-5

5. Yoon JW. The roll of viruses and environmental factors in the induction of diabetes. Carr. Top Environ. Microbiology 1990; 164: 95-123

6. Shariff $\mathrm{Mk}$, Hemtages $\mathrm{R}$ and Ciard $\mathrm{M}$. Intrathecal Immune response in patients with the post-poliosyndrome. New England Journal of Medicine 1991; 325: 749-755.

7. Woodal CJ, Riding MH and Clements GB. Sequences specific for enteroviruses detected in spiral cord from patients with motor neurone disease. British Medical Journal 1994; 308; 1541 1543

8. Clements Gb, Mcgarry F, Naim C. et al. The detection of enterovirus specific RNA in serum the relationship to chronic fatique. J. Med. Virol 1995; 45: 151-166

9. Pallansch MA, Roos RP. Enteroviruses: polioviruses, coxsackieviruses, echoviruses, and newer enteroviruses. In: Knipe Dm, Howley PM, Griffin DE, Lamb RA, Martin MA, Riozman B, Straus SE, editors. Fields virology. $4^{\text {th }}$ ed. Philadelphia: Lippincott Williams \& Wilkins, 2001; p723-775.

10. Baboonian C, Davies MJ, Booth JC, McKenna WJ. Coxsackie B viruses and human heart disease. Curr Top Microbiol Immunol 1997; 223:31-52.

11. Li Y, T Peng, Y Yang, C Niu, L Archard, and H Zhang. High prevalence of enteroviral genomic sequences in myocardium from cases of endemic cardiomyopathy (Keshan disease) in China. Heart 2000; 83(6): 696-701.

12. Andreoletti L, Bourlet T, Moukassa D, Rey L, Hot D, Li Y, Lambert V, et al. Enteroviruses can persist with or without active viral replication in cardiac tissue of patients with end-stage ischemic or dilated cardiomyopathy. J. Infect. Dis 2000; 182 (4), 1222-1227.

13. Chapman NM, KS Kim, KM Drescher, K Oka, S Tracy. 52 terminal deletions in the genome of a coxsackievirus B2 strain occurred naturally in human heart. Virology, 2008 (in press) YVIRO04622; No. of pages: 12; 4C: 2

14. Magnani JW, Dec GW. Myocarditis: current trends in diagnosis and treatment. Circulation 2006; 113: 876-890. 
15. Heymans S. Myocarditis and heart failure: need for better diagnostic, predictive, and therapeutic tools. European Heart Journal2007; 28(11):12791280

16. Mahrholdt H, Wagner A, Deluigi CC, Kispert E, Hager S, Meinhardt G, et al. Presentation, patterns of myocardial damage, and clinical course of viral myocarditis. Circulation 2006; 114:1581-1590.

17. Heymans S, Pauschinger M, De Palma A, Kallwellis-Opara A, Rutschow S, Swinnen M, et al. Inhibition of urokinase-type plasminogen activator or matrix metalloproteinases prevents cardiac injury and dysfunction during viral myocarditis. Circulation 2006; 114:565-573.

18. Maekawa Y, Ouzounian M, Opavsky MA, Liu PP. Connecting the missing link between dilated cardiomyopathy and viral myocarditis: virus, cytoskeleton, and innate immunity. Circulation, 2007; 115:5-8.

19. Caforio ALP, Calabrese F, Angelini A, Tona F, Vinci A, Bottaro S, Ramondo A, et al. A prospective study of biopsy-proven myocarditis: prognostic relevance of clinical and aetiopathogenetic features at diagnosis. Eur Heart Journal 2007; 28:1326-1333.

20. Pauschinger M, Doerner A, Kuehl U, Schwimmbeck PL, Poller W, Kandolf R, Schultheiss HP. Enteroviral RNA replication in the myocardium of patients with left ventricular dysfunction and clinically suspected myocarditis. Circulation 1999; 99: 889-895.

21. Kuhl U, Pauschinger M, Seeberg B, Lassner D, Noutsias M, Poller W, Schultheiss HP. Viral persistence in the myocardium is associated with progressive cardiac dysfunction. Circulation 2005a; 112:1965-1970.

22. Tschöpe C, Bock CT, Kasner M, Noutsias M, Westermann D, Schwimmbeck PL, et al. Heart Failure-High Prevalence of Cardiac Parvovirus B19 Infection in Patients With Isolated Left Ventricular Diastolic Dysfunction. Circulation 2005; 111:879-886.

23. Kuhl U, Pauschinger M, Noutsias M, Seeberg B, Bock T, Lassner D, Poller W, Kandolf R, Schultheiss HP. High prevalence of viral genomes and multiple viral infections in the myocardium of adults with 'idiopathic' left ventricular dysfunction. Circulation 2005b; 111:887-893.

24. Schiff GM, Sherwood JR. Clinical activity of pleconaril in an experimentally induced coxsackievirus A21 respiratory infection. J. Infect. Dis 2000; 181:20-26.

African Health Sciences Vol 13 Issue 4 December 2013
25. Romero JR. Pleconaril: a novel antipicornaviral drug. Expert Opin. Investig. Drugs 2001; 10:369379.

26. Rotbart HA, Webster AD. Treatment of potentially life threatening enterovirus infections with pleconaril. Clin. Infect. Dis 2001; 32:228235.

27. Elfaitouri A, Nahla M, Jan Fohlman RA, Gun F, Go "ran F, Lars M, Jonas B. Quantitative PCREnhanced Immunoassay for Measurement of Enteroviral Immunoglobulin M Antibody and Diagnosis of Aseptic Meningitis. Clinical and Diagnostic Laboratory Immunology 2005; 12(2): 235241

28. World Health Organization (WHO). Manual for the Virological Investigation of Poliomyelitis. Geneva, Switzerland: World Health Organization, 2004.

29. Ferreira Junior AG, Ferreira SMAG, Gomes MLC, Linhares ACT. Enteroviruses as a possible cause of myocarditis, pericarditis and dilated cardiomyopathy in Belum, Brazil. Brazilian Journal of Med. Biol. Res 1995; 28(8):869-874.

30. Muir P, F Nicholson, SJ Illavia, TS McNeil, JF Ajetunmobi, H Dunn, WG Starkey, KN Reetoo, N RB Cary, J Parameshwar, JE Banatvala. Serological and molecular evidence of enterovirus infection in patients with end-stage dilated cardiomyopathy. Heart 1996;76:243-249

31. Rey L, Valérie Lambert, Pierre Wattré, Laurent Andréoletti. Detection of enteroviruses ribonucleic acid sequences in endomyocardial tissue from adult patients with chronic dilated cardiomyopathy by a rapid RT-PCR and hybridization assay. Journal of Medical Virology

l 2001; 64(2): 133-140

32. Why HJ, Meany BT, Richardson PJ, Olsen EG, Bowles NE, Cunningham L, Freeke CA, Archard LC. Clinical and prognostic significance of detection of enteroviral RNA in the myocardium of patients with myocarditis or dilated cardiomyopathy. Circulation 1994; 89: 2582-2589.

33. Omonayajo TB. Isolation and Identification of Enteroviruses in Non-Polio AFP in Nigeria. An M.Sc. Project in the Dept. of Virology, University of Ibadan, Nigeria, 2002; 96p

34. Honeyman, M. How robust is the evidence for viruses in the induction of type 1 diabetes? Current Opinion Immunology 2005; 17(6): 616-623.

35. Ajabaluku OV. Isolation of Coxsackieviruses from Hypertensive Patients with Heart Failure. 
An M.Sc. Project in the Dept. of Virology. University of Ibadan, Nigeria, 2006; 81p

36. Adejokun AT. Isolation of Enteroviruses in Patients Presenting with Dilated Cardiomyopathy. An M.Sc. Project in the Dept. of Virology. University of Ibadan, Nigeria 2006; $77 \mathrm{p}$

37. Skarsvik S, Puranen J, Honkanen J. Decreased in vitro type 1 immune response against coxsackie virus B4 in children with type 1 diabetes. Diabetes 2006; 55(4): 996-1003.

38. Trallero G, Casas I, Tenorio A, Echevarria JE, Castellanos A, Lozano A, Brena PP. Enteroviruses in Spain: virological and epidemiological studies over 10 years (1988-97). Epidemiol Infect 2000; 124(3):497-506.

39. Wenner HA, Abel D, Olson LC, Burry VF. A mixed epidemic associated with echoviruses types 6 and 11. Virologic clinical and epidemiologic studies. Am J Epidem 1981; 114:369-378

40. Antia AU, Cockshott WP, Thorpe GJ. Idiopathic cardiomegaly in Nigeria Children. British Heart Journal 1969; 2:178-183.

41. Figulla HR, Stille-Siegerer M, Mall G, Heim A, Kreuzer H. Myocardial enterovirus infection with left ventricular dysfunction: a benign disease compared with idiopathic dilated cardiomyopathy. J. Am. Coll. Cardiol 1995; 25:1170-1175.

42. Grumbach IM, Heim A, Pring-Akerblom I, Vonhof S, Hein WJ, Muller G, Figulla HR. Adenoviruses and enteroviruses as pathogens in myocarditis and dilated cardiomyopathy. Acta Cardiol 1999; 54:83-88.

43. Frustaci A, Chimenti C, Calabrese F, Pieroni M, Thiene G, Maseri A. Immunosuppressive therapy for active lymphocytic myocarditis: virological and immunologic profile of responders versus nonresponders. Circulation 2003; 107: 857-863.

44. Fujioka S, Koide H, Kitaura Y, Duguchi H, Kawamura K. Coxsackieviruses B pathogenic role in progression of dilated cardiomyopathy. Am. Heart J 1995; 131 (4):760-765

45. Fujioka S, Kitaura A, Deguchi H, Kawamura K, Isomura T, Suma H, Shimizu A. Evaluation of viral infection in the myocardium of patients with idiopathic dilated cardiomyopathy. J. Am. Coll. Cardiol 2000; 36:1920-1926.

46. Bowles NE, Bowles NE, Ni J, Kearney DL, Pauschinger M, Schultheiss HP, McCarthy R, et al. Detection of viruses in myocardial tissues by polymerase chain reaction: evidence of adenovirus as a common cause of myocarditis in children and adults. J. Am. Coll. Cardiol 2003; 42:466-472

47. Wojnicz R, Nowalany-Kozielska E, Wojciechowska C, Glanowska G, Wilczewski P, Niklewski T, et al. Randomized, placebocontrolled study for immunosuppressive treatment of inflammatory dilated cardiomyopathy: two-year follow-up results. Circulation 2001; 104:39-45. 